\title{
'Ours will be a tent': The meaning and symbolism of the early Aboriginal Tent Embassy ${ }^{1}$
}

\author{
Tobias Campbell \\ The Australian National University
}

Abstract: The Aboriginal Tent Embassy was founded in 1972 to reflect the alienation felt by many Aboriginal people from contemporary political processes and policy in Australia. The establishment of the Embassy also reflected new ideas about how Aboriginal activists viewed their struggle for justice. In the decades following the Second World War, Aboriginal identity became increasingly nationalised. An unprecedented level of pan-Aboriginal identification and solidarity emerged during the 1950s and 1960s that enabled activists to unite at the Embassy. The American Black Power movement was a major influence on those activists who took to the lawns of what was then Australia's Parliament House, and the wise stylistic decisions made while the Embassy was being formed were also crucial to the success of the Embassy as a symbol. These stylistic elements focused on the use of a tent-a 'brilliant hijacking of the nationally symbolic space-that was able to capture the deprived living conditions of so many Aboriginal communities. More subtly, the Embassy was an exercise in satire that helped to undermine the Federal Government and win over many supporters. The Embassy was an adventure in ideas for a generation of activists who refused to accept continued alienation. To this day, the Embassy continues its fight for Aboriginal sovereignty and land rights.

That Aboriginal people were protesting in 1972 is unsurprising. On the other hand, the decision to erect a tent 'embassy' on the lawns of Parliament House was astonishing, provocative and confronting. It has since become an enduring symbol and residence for activists fighting for Aboriginal sovereignty and self-determination. For more

1 This article was the result of a research project for the research-intensive 'Making History' course at The Australian National University. 
than 40 years, the Aboriginal Tent Embassy has personified Aboriginal resilience, reminding Australians that Australia 'always was, always will be, Aboriginal land!'.

This article examines the meanings that activists aimed to instil in the Embassy by exploring the ideological influences that inspired them. These included the struggle for land rights and sovereignty dating back to 1788 , the arrival of the Black Power movement in Australia during the late 1960s and the emergence of an unprecedented pan-Aboriginal political identity in the decades after the Second World War. It also considers the Embassy site and the stylistic features of what was, and still is, a politically charged symbol. The meaning embedded in the 'Tent Embassy' is one that activists have designed, in the words of Paul Muldoon and Andrew Schaap, to 'strategically exploit the ambiguous status of Aboriginal people as citizens within and without the community presupposed by the Australian state', to contend that Australia must abide by Aboriginal sovereignty rather than the other way around. ${ }^{2}$

The Embassy was important in many ways. The response it was able to provoke from both the opposition of the day, the Australian Labor Party, and the governing Coalition of the Liberal Party and the Country Party was enormous for Aboriginal activism. As Muldoon and Schaap argue, the Embassy represents a kind of 'constituent power' for Aboriginal people and their supporters. ${ }^{3}$ This article expands on that interpretation, examining the active construction of the symbol of the tent as activists attempted to realise a true Embassy, legitimised by widespread popular support from the Aboriginal community. To achieve this, activists sought to make the Embassy representative and relatable to everyday Aboriginal people and not only those with relatively extensive amounts of social capital.

2 Paul Muldoon and Andrew Schaap, 'Aboriginal Sovereignty and the Politics of Reconciliation: The Constituent Power of the Aboriginal Embassy in Australia', Environment and Planning D: Society and Space 30, no. 3 (2012), 534.

3 Muldoon and Schaap, 'Aboriginal Sovereignty and the Politics of Reconciliation', 534. 


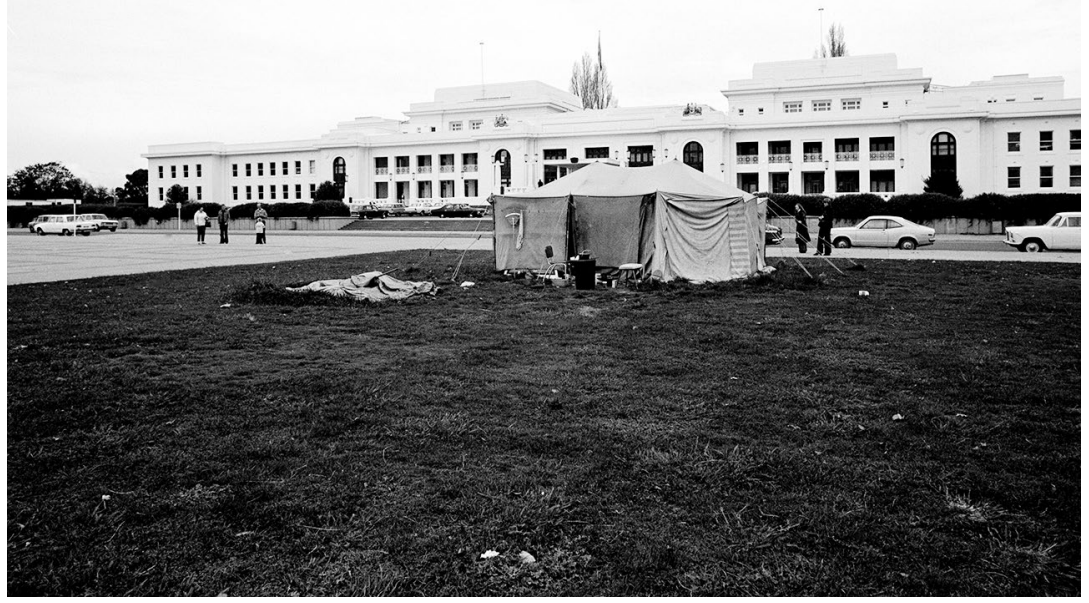

Figure 1: The Aboriginal Tent Embassy juxtaposed against Old Parliament House during the demonstration in support of the Yirrkala petition on land rights to prime minister Gough Whitlam, 1974.

Collection: National Archives of Australia, A10/7/74/4A.

Occupying the lawn before what was then Parliament House, in the centre of the national capital, was a significant spatial and cultural disruption. For this reason, the satirical irony of a 'tent' Embassy was extremely effective in reaching out to, and generating support among, Aboriginal people. From its foundation, the symbolic power of the Embassy resonated with Aboriginal experiences of dispossession, displacement and, perhaps less appreciated but no less important, spoke to a feeling that their existence was in juxtaposition with the cultural norms and formal institutions of twentieth-century Australia.

The Embassy has been controversial and has often drawn the ire of politicians, particularly within the Liberal Party. This tension returned to the spotlight in January 2012 when protesters, reacting to comments made by Opposition Leader Tony Abbott, crowded around the Old Parliament House restaurant to voice their objections. Abbott had claimed that the Embassy was no longer relevant. ${ }^{4}$ This incident led to Abbott

4 Emma Griffiths, 'Abbott Defends Tent Embassy Comments', $A B C, 27$ January 2012, accessed at www.abc.net.au/news/2012-01-27/abbott-praises-gillard-over-protest-response/3796290. 
and prime minister Julia Gillard being 'bundled out' of the restaurant by bodyguards and police officers. ${ }^{5}$ The limited size of the historiography of the Embassy might reflect its continued political currency. But many of the contributions that have been made to the field are also impressively comprehensive. Heather Goodall's Invasion to Embassy: Land in Aboriginal Politics in New South Wales 1770-1972 argues that the Embassy evolved out of the struggle for land rights-a struggle that dates back to before the arrival of the First Fleet in $1788 .{ }^{6}$ Kathy Lothian, writing in the mid-2000s, offers an excellent analysis of the role that the Black Panther movement played in revitalising Aboriginal protest. ${ }^{7}$ More recently, Schaap and Muldoon have turned their attention to the Embassy as a symbol, particularly in relation to Aboriginal sovereignty and the state as created under the Australian Constitution. In 2013, Gary Foley, Andrew Schaap and Edwina Howell edited a comprehensive, insightful overview of the Embassy and its history. This book explores the emergence of the Embassy, the active construction of the tent as a political symbol and how it reflects activists' objectives. $^{8}$

The Tent Embassy was a potent symbol of Aboriginal resilience amid the political turbulence of the early 1970s. The refusal by prime minister Billy McMahon to recognise Aboriginal land rights inherent in Aboriginal sovereignty helped give meaning to the Embassy as an assertion of sovereignty. On 25 January 1972, McMahon announced that a new government policy would see land leased to Aboriginal people on fixed terms, without any acknowledgement of ownership, guarantee of continued possession or promise of compensation. ${ }^{9}$ The decision to establish an Embassy reflected the fundamental principle at the heart of Aboriginal activism: that Australia is Aboriginal land because sovereignty was never ceded. The Embassy had its own 'ministers' and 'mimicked

5 Ben Packham and Lanai Vasek, 'Gillard, Abbott Escorted under Guard amid Aboriginal Tent Embassy Protest', The Australian, 27 January 2012, accessed at www.theaustralian.com.au/archive/ national-affairs/gillard-abbott-escorted-under-guard-amid-aboriginal-tent-embassy-protest/newsstory/1be365d53375af6895c60fc24bed0d3d.

6 Heather Goodall, Invasion to Embassy: Land in Aboriginal Politics in New South Wales, 1770-1972 (St Leonards: Allen \& Unwin, 1996).

$7 \quad$ Kathy Lothian, 'Seizing the Time: Australian Aborigines and the Influence of the Black Panther Party, 1969-1972', Journal of Black Studies 35, no. 4 (March 2005). See also Kathy Lothian, 'Moving Blackwards', in Transgressions: Critical Australian Indigenous Histories, ed. Ingereth Macfarlane and Mark Hannah (Canberra: ANU E Press, 2007), 19-34.

8 Gary Foley, Andrew Schaap and Edwina Howell, eds, The Aboriginal Tent Embassy: Sovereignty, Black Power, Land Rights and the State (Milton Park, Abingdon and Oxon: Routledge, 2013).

9 Goodall, Invasion to Embassy, 338. 
the state by claiming the features of statehood'. ${ }^{10}$ Flags flew above the lawns; first the pan-African flag for its association with Black Power and subsequently the red, black and yellow Aboriginal flag designed by Harold Thomas. ${ }^{11}$

Many archival sources from the Embassy's early days do not refer to 'sovereignty' but instead use the words 'land rights'. ${ }^{12}$ This is puzzling at first because later commentaries by influential Embassy officials and key supporters refer frequently to sovereignty. One example is Isabel Coe's statement during an interview in 2000 where she emphasised the fact that Aboriginal people 'have never ceded [...] sovereignty from one end of the country to the other'. ${ }^{13}$ Michael Anderson described the Embassy as emerging 'to high-light [sic] the fact that this land was taken from our Aboriginal people'. ${ }^{14}$ Yet, the Embassy's declaration of sovereignty was not issued until 1992. ${ }^{15}$ Anderson later clarified what he meant by the term sovereignty, recalling a suggestion by another prominent activist, Chicka Dixon. Interviewed in 2011 for the National Film and Sound Archive, Anderson described the Embassy as being based on '[1] and rights and sovereignty. Sovereignty was a key issue. Because the two go together, as far as we are concerned'. ${ }^{16}$ The statement illustrates the fundamental and enduring relationship between sovereignty and land rights for Aboriginal activists.

The entire basis of the claim for land rights is sovereignty, and activists expressed a desire to fight for sovereignty until it manifested itself in the form of land rights. Chicka Dixon, inspired by a Native American protest on Alcatraz Island in California, had previously proposed that Aboriginal activists occupy Sydney Harbour's Pinchgut Island, declaring sovereignty (Anderson recalls him using the word specifically) over it. ${ }^{17}$

10 Edwina Howell, 'Black Power-By Any Means Necessary', in The Aboriginal Tent Embassy, 80.

11 Gary Foley, 'A Reflection of the First Thirty Days of the Embassy', in The Aboriginal Tent Embassy, 30 .

12 Donation form in the name of Sammy Watson Jr on behalf of the Aboriginal Tent Embassy, 1972, in Embassy Ephemera Material, National Library of Australia (NLA), 1075946.

13 Isabel Coe, 'The Aboriginal Tent Embassy 28 Years After it was Established', interview by Irene Watson, Indigenous Law Bulletin 5, no. 1 (2000), 48. The spelling of 'Isabel' as 'Isobell' appears intermittently and the correct spelling is unclear.

14 Michael Anderson, 'Why an Embassy' [unpublished typescript] (1972), Australian Institute of Aboriginal and Torres Strait Islander Studies (AIATSIS), PMS 5101.

15 Muldoon and Schaap, 'Aboriginal Sovereignty and the Politics of Reconciliation', 534.

16 Michael Anderson, 'Founding of the Embassy', interview by Brenda Gifford, recorded at the National Film and Sound Archive, 17 June 2011, in The Aboriginal Tent Embassy, 120.

17 Anderson, 'Founding of the Embassy', 118. 
Anderson says that these sorts of conversations were held frequently in the early 1970s and ultimately inspired the Embassy concept. The Embassy was supposed to represent the alienation of Aboriginal people from the Australian state just as other embassies represented foreign nations and peoples. Gary Foley, speaking in 2011, recounted that the 'government had declared us aliens in our own land [...] we need an Embassy just like all the other aliens'. ${ }^{18}$

The failure of the Australian Federal Government to recognise Aboriginal land rights meant that the sovereignty of the Commonwealth competed with that of Aboriginal people. With no mechanism to assert their sovereignty in the way that other states might, the Embassy was designed to alleviate this and to constitute a representative mechanism. The underlying principle was that if Aboriginal sovereignty is excluded from the Australian state, Aboriginal people will continue to live, abide by and assert it, separately from the state. For Anderson and his co-founders, sovereignty was manifested in land ownership. Goodall captures this position in her claim that the cultural significance of land was the 'authority for the Embassy'. ${ }^{19}$ It was concerned with the pursuit of an 'independent platform' for Aboriginal people—an objective it maintains today. ${ }^{20}$

Beyond land rights, the Embassy was also shaped by the Black Power movement and its idea of the 'black nation'. Exposure to images of AfricanAmerican civil rights advocacy made available by advances in media in the preceding decade helped make Black Power more accessible to Aboriginal activists. Indeed, the Embassy flew a pan-African flag (albeit upside down) in its early days. ${ }^{21}$ There was significant overlap between Black Power membership and involvement in the Embassy, including Michael Anderson, Billy Craigie, Tony Coorey, Bobbi Sykes, Gary Foley, John Newfong, Paul Coe and, of course, Denis Walker. While campaigning on the Embassy's behalf for land rights in 1972, Anderson referred to the 'Black Australian Nation' clearly framing Aboriginal activism in nationalistic terms. ${ }^{22}$ And

18 Howell, 'Black Power-By Any Means Necessary', 75.

19 Goodall, Invasion to Embassy, 348-49.

20 'Role of the Embassy', 19 April 1976, Records of the Aboriginal Embassy, AIATSIS, MS 4013 1/2.

21 John Maynard, 'Tracking Back: Parallels Between the 1920s Aboriginal Political Movements and the 1972 Tent Embassy', in The Aboriginal Tent Embassy, 93-94.

22 Aboriginal Tent Embassy, 'Aboriginal Embassy, Canberra', Newsletter on Aboriginal Affairs, no. 2 (1972), AIATSIS, RS 21/18, 8-9. 
the Embassy reflected key Black Power aspirations: black autonomy ${ }^{23}$ and potentially separatism. ${ }^{24}$ Black Power meant different things to different people in 1972. Sykes was quick to concede this and cautioned the public against misinterpretation. Recognising that for many Black Power connoted violence, she argued instead that its message was one of anti-assimilation and the promotion of black voices. ${ }^{25}$ The Embassy has been subject to very similar misinterpretation or misapprehension ever since-and this is probably a further indication of the role Black Power activists played in its establishment. The aspirations of the 'black nation' have certainly found unique expression in the Embassy on many occasions. A recent example was the corroboree that welcomed protester Clinton Pryor to Canberra in September 2017 after he had traversed the continent. ${ }^{26}$ Clearly, the Embassy constitutes a space for expression of Aboriginality and that much of this expression came from Black Poweraffiliated activists in 1972 .

The Black Power movement was part of a broader shift in Aboriginal politics that was at its peak in 1972. Previously, Aboriginal political agitation had been relatively localised. But in the late 1960s and early 1970s an emerging sense of a shared experience, collective unity and pan-Aboriginal identity was consolidated by activists—often in urban regions. ${ }^{27}$ Extensive migration of Aboriginal people to urban areas in the 1950s played a significant part in this development. ${ }^{28}$ Activists remarked on the implications of this change and took note of the way that the Embassy made it visible. Roberta Sykes observed that 'Alice Springs, reserve, urban [were] all connected through investment in the Embassy'. ${ }^{29}$ More recently, in 2013, Gary Foley said that the 'provocative act' of the Embassy 'seemed to invite a strong response from Aboriginal activists who had for the previous twelve months been staging major land rights

23 Roberta Sykes, 'Black People Want to Control their Own Destiny', Newsletter on Aboriginal Affairs, no. 2 (1972), 8-9.

24 Black Panther Party of Australia, 'Black Panther Party of Australia Platform and Program, July 1972', Newsletter on Aboriginal Affairs, no. 2 (1972), 10.

25 Sykes, 'Black People Want to Control their Own Destiny', 8-9.

26 Emily Baker, 'Clinton Pryor Arrives in Canberra after Walking from Western Australia', Canberra Times, 3 September 2017, accessed at www.canberratimes.com.au/act-news/clinton-pryorarrives-in-canberra-after-walking-from-western-australia-20170903-gy9ty $7 . h t m l$.

27 Scott Robinson, 'The Aboriginal Embassy: An Account of the Protests of 1972', in The Aboriginal Tent Embassy, 4.

28 Ann Curthoys, 'The Freedom Ride and the Tent Embassy', in The Aboriginal Tent Embassy, 100.

29 Roberta Sykes, 'Hope's Ragged Symbol', Nation Review, 29 July-4 August, 1972, AIATSIS, p 11891, p SYK, 1170. 
demonstrations in southern Australian capital cities'. ${ }^{30}$ The Embassy consolidated the energy of activists from an incredibly wide array of communities to an unprecedented degree.

Prominent Aboriginal activists spoke about Aboriginal protest as more far-reaching than any one local (or even perhaps national) community. Paul Coe even referred to the 'black struggle' and labelled it as struggle of the 'third world'. Aboriginal people were looking beyond their local communities and all while attempting to situate their efforts in the context of a postcolonial society. Goodall adds further weight to this argument by identifying key events leading up to 1972 that helped forge a sense of solidarity among Aboriginal people across Australia. Prominent instances of Aboriginal activism such as the Freedom Rides in New South Wales in 1965, the Gurindji walk-off from Wave Hill station in the Northern Territory in 1966-67, and the decision of Mr Justice Blackburn in Milirrpum $v$ Nabalco in 1971 that denied legal recognition to the plaintiffs' (Yolngu) assertion of customary ownership. ${ }^{31}$ Aborigines Advancement League activity, protesting against British nuclear testing at Maralinga in the 1950s and the campaign for Yes in the 1967 Referendum are all poignant examples. ${ }^{32}$

While tracing the origins of pan-Aboriginal activism to the 1920s, Aboriginal activist, academic and Elder Gordon Briscoe contends that the Embassy's greatest significance was its impact 'on the psyche of Aboriginal identity', because it 'represented the theoretical as well as the human face of Aboriginal political consciousness'. ${ }^{33}$ In other words, the Embassy helped consolidate the development of pan-Aboriginal political identity in the early 1970s. The claim that sovereignty had never been ceded was key to the establishment of the Embassy, but Black Power also provided much of the ideology and inspiration. It is for this reason that the type of Aboriginal activism that converged on the lawns of Parliament House looked very different from anything that had surfaced publicly before the 1960s.

30 Foley, 'A Reflection on the First Thirty Days of the Embassy', in The Aboriginal Tent Embassy, 22.

31 Goodall, Invasion to Embassy, 323, 325 \& 337. See also Muldoon and Schaap, 'Aboriginal Sovereignty and the Politics of Reconciliation', 537.

32 Gordon Briscoe, 'The Origins of Aboriginal Political Consciousness and the Aboriginal Embassy, 1907-1972', in The Aboriginal Tent Embassy, 43 \& 47-48. For further reading about the 1920s origins of pan-Aboriginal activism see Chapter 6 of the same volume (written by John Maynard).

33 Briscoe, 'The Origins of Aboriginal Political Consciousness and the Aboriginal Embassy', 53. 
Of course, the Embassy enabled activists to seize the attention of ministers and senior bureaucrats. Many expressed deep uncertainty about what the Embassy represented. Two ministers were particularly vocal in their criticisms of the Embassy: Interior Minister Ralph Hunt said that activists should desist and be 'sensible'; ${ }^{34}$ and the Minister for the Environment, Arts and Aborigines, Peter Howson, allegedly dissatisfied after receiving the portfolio of 'trees, boongs and poofters', was disparaging. ${ }^{35}$ While correctly identifying the Embassy to be an assertion of a 'sovereign state', Howson was quick to attack its implicit separatism, which he compared to apartheid. ${ }^{36}$ Yet, this hostile, contemptuous response vindicated the Embassy's effectiveness as a symbol. McMahon's refusal of land rights in January 1972 had confirmed, for many Aboriginal people, a deep sense of alienation at the hands of the Commonwealth. Moreover, this alienation was realised through the day-to-day mechanics of the Australian political system. While Hunt and Howson advocated the 'sensible' pursuit of political objectives through mainstream political institutions, they also highlighted the McMahon Government's dismissiveness. By highlighting Aboriginal exclusion and asserting Aboriginal difference, activists were refusing to confine agitation to the 'traditions' of Anglo-Australian culture. Instead, they threw down the gauntlet to the Commonwealth. The response of Hunt and Howson merely reinforced the activists' claim that Australia's political system was ill-equipped to respond to any kind of Aboriginal assertiveness.

Having condemned the Embassy for (supposedly) advocating apartheid, the Federal Government proceeded to try and lay the issue to rest, resolving to remove the Embassy. On 17 July 1972, Embassy officials were served with notice of an ordinance (that had been adjusted to apply specifically to the Embassy) forbidding continued occupation of the lawns in front of Parliament House. Approximately 72 hours later, police tore down the Embassy. Goodall reports that around 200 Aboriginal people and supporters re-established the Embassy on 23 July but that this was again dismantled by a particularly large assembly of some 360 police officers. ${ }^{37}$ The confrontation between demonstrators and police was

\footnotetext{
34 'Hunt Offers to Meet Aborigines', Canberra Times, 29 July 1972, 1.

35 Mungo MacCallum, 'Peter Howson, Minister for "Trees, Boongs and Poofters"', Crikey, 5 February 2009, accessed at www.crikey.com.au/2009/02/05/peter-howson-minister-for-trees-boongsand-poofters/.

36 'Hunt Offers to Meet Aborigines', 1.

37 Goodall, Invasion to Embassy, 350-51.
} 
violent. One Embassy spokesperson described it 'as the day when Black brothers and sisters with the solid support of their white brothers stood for human rights. The voices [were] raised against the violence'. ${ }^{38}$ In his poem 'Breath of Life', poet and activist Kevin Gilbert wrote of 'those men/ and the women and children/ who have put their heads/ against policemen's batons. ${ }^{39}$

Following the second police removal, some 2,000 demonstrators returned to raise the Embassy anew. Many of the demonstrators were Aboriginal, but the crowd also included many non-Aboriginal students from The Australian National University. On this occasion, the Embassy stood. ${ }^{40}$ Media coverage of the police using force against the protesters helped garner public support. This was a miscalculation on the part of the Australian Federal Police and the government. The London Times correspondent Stewart Harris, a passionate advocate for Aboriginal rights, commented on the spectacle of the Embassy and the nationwide television broadcast increased awareness and public sympathy. Harris further observed:

the experience of the Embassy and especially the brutal way it [the Embassy] was endorsed by government brought many older and perhaps more conservative Aborigines [sic] in behind the young radical leaders, after much initial doubt and suspicion of their motives. ${ }^{41}$

This miscalculation meant that the heavy-handedness used to try and silence activists and destroy the Embassy actually helped legitimise it for both Aboriginal and non-Aboriginal people.

In contrast to his Coalition adversaries, Labor Opposition Leader Gough Whitlam demonstrated a willingness to engage with the Embassy. He attended the Embassy in early 1972 to speak with activists. At the time, it was widely regarded that the Australian Labor Party was more sympathetic to Aboriginal causes than the Liberal Government. ${ }^{42}$ The fact that the only Aboriginal parliamentarian of the time, Senator Neville

38 'Sunday July 23-The Aboriginal Embassy', Newsletter on Aboriginal Affairs, no. 3 (1972), AIATSIS, RS 21/18, 6.

39 'Affinity—Info Compiled @ the Aboriginal Tent Embassy', NLA, 3045606, 1.

40 Goodall, Invasion to Embassy, 350-51.

41 Nick McLaren, 'Black Power, ASIO and Media Framing of the 1972 Aboriginal Tent Embassy', AIATSIS, MS 4862, 52.

42 Lorna Lippmann, 'Some Policy Differences Between Aboriginal Organizations the Major Political Parties', Newsletter on Aboriginal Affairs, no. 2 (1972), 4. 
Bonner, was a Liberal did not alter the government's position. John Newfong wrote excitedly of the strong sense of accomplishment felt by activists after Whitlam's visit. The Embassy had delivered its five-point plan for land rights to Whitlam, which included statehood for the Northern Territory as an Aboriginal state, land and mining rights to reserve lands and capital cities, preservation of sacred sites and compensation for land the Crown continued to possess.

The meeting with Whitlam enabled the Embassy to be heard as a genuine representative organ. Although Whitlam did not commit to all of the demands, the fact that he had dignified the Embassy with his attendance, listened to activists sincerely and promised to recognise land rights inspired tremendous pride at the site. ${ }^{43} \mathrm{Co}$-founder Michael Anderson was equally positive about the meeting, later describing it as a 'defining moment' and elaborating that ' $[0]$ ne of the key things that emerged [...] was [Whitlam's message] [...] you young fellas are doing a wonderful thing taking the fight to the Australian public'. ${ }^{44}$ By the end of 1972, Whitlam was prime minister. Whereas the Coalition Government had been unreceptive to the land rights message, the meeting with Whitlam was an example of the Embassy enabling Aboriginal voices to reach politicians at the highest level.

The activists who had built the Embassy had intended for it to represent all Aboriginal people and they worked diligently to ensure that it was a representative institution that many Aboriginal people could relate to. The fact that the Embassy was a tent was incredibly symbolic. Activists quickly grew conscious of the symbolism that emerged from their re-erection of the Embassy after government attempts to destroy it. The use of a tent symbolised the impoverished living conditions of Aboriginal people across the country. The site was both a traditional NgunnawalWiradjuri meeting ground and the ground on which the Australian Parliament stood. ${ }^{45}$ The space was therefore one that illustrated the illegal and unjust authority exercised by the state over Aboriginal life. The Embassy's presence disrupted idealised political ideas of inclusivity and representation and was even satirical in nature. But although the Embassy was an exercise of satire, and even self-deprecation, it was sincere in its

43 John Newfong, 'The Aboriginal Embassy: Its Purpose and Aims', Identity 1, no. 5 (July 1972), 4-6.

44 McLaren, 'Black Power', 46.

45 'Register of the National Estate Database Place Report', Embassy Ephemera Material, NLA, 1075946, 20. 
attempt to undermine the Commonwealth, to make it look foolish and in doing so highlight what Muldoon and Schaap label its 'defective claim to sovereignty. ${ }^{46}$

Efforts to violently remove the Embassy from the lawns of Parliament House also meant that it became a symbol of Aboriginal resilience. Nicole Watson has documented the initial discussions between Michael Anderson, Billy Craigie, Tony Coorey and Bertie Williams and the police: when told that the Embassy would remain until land rights were granted the police exclaimed that the Embassy might be there 'forever'. ${ }^{47}$ With many land rights issues still unresolved, the Embassy continues to occupy the same lawn today. To many, the struggle to keep re-erecting the Embassy evoked a deep sense of empathy, as activists demonstrated much resilience and adaptability: two attributes with which Aboriginal communities have become well acquainted as they have fought and endured discrimination, survived genocide and maintained their culture.

The choice of the Embassy's site has been labelled by Iveson as 'a brilliant hijacking of the nationally symbolic space'. ${ }^{48}$ Amid the buildings of the Parliament, High Court, National Library, National Gallery and later Reconciliation Place, and in perfect alignment across the lake with Anzac Parade and the Australian War Memorial, the Embassy throws Aboriginal sovereignty into the spotlight, contesting the narratives that these institutions represented at the time. ${ }^{49}$ In doing so, it realises an 'ontological disturbance' to the Australian War Memorial, issuing what Nicoll calls a 'challenge to a white racial regime'. ${ }^{50}$ Given the failure of the Memorial to commemorate the Frontier Wars-in contrast to its willingness to commemorate Aboriginal soldiers who served the Commonwealth-the assimilation of Aboriginal identity into the citizenry of the Australian state is once again made a precondition to recognition or participation. The Embassy's agitation is therefore well directed, in the words of Muldoon and Schaap, 'frustrating attempts by the constituted power to monopolize

46 Muldoon and Schaap, 'Aboriginal Sovereignty and the Politics of Reconciliation', 534.

47 Nicole Watson, 'What Do We Want? Not Native Title, That's For Bloody Sure', in The Aboriginal

Tent Embassy, 294.

48 Kurt Iveson, 'The Spatial Politics of the Aboriginal Tent Embassy, Canberra', in The Aboriginal

Tent Embassy, 251.

49 Paul Muldoon and Andrew Schaap, 'The Constitutional Politics of the Aboriginal Embassy', in The Aboriginal Tent Embassy, 225 \& 228.

50 Fiona Nicoll, 'War by Other Means: The Australian War Memorial and the Aboriginal Tent Embassy in National Space and Time', in The Aboriginal Tent Embassy, 267 \& 282. 
the meaning of public space'.$^{51}$ Similarly, the Embassy operates in stark contrast to the narrative of progress depicted by Reconciliation Place. ${ }^{52}$ The fact that the Embassy's occupation was able to continue because of Aboriginal exclusion from laws relating to citizenship has only heightened the ironic currency of its spatial agitation.

As a symbol that represents the political interests of Aboriginal people, the Embassy was also constructed to reflect the deprived living conditions that so many Aboriginal people faced in 1972, deprivation that continues to affect many Aboriginal people today. There were two underlying reasons why this was especially important. First, gunyahs, ${ }^{53}$ humpies and tents offered commentary on homelessness in the personal sense, particularly in places like Alice Springs. They brought together the 'reserve [and] urban', and the 'poor and shabby'. ${ }^{54}$ Activists felt it was crucial that the Embassy be relatable to Aboriginal people, especially those battling poverty and homelessness. Roberta Sykes said as much to officials at a 1972 meeting with Department of Interior officials where it was suggested that the Embassy might be relocated to an office. Sykes' recollection of her objection is: 'We don't want your deluxe suites that our people can't relate to, we don't want fancy accommodation [...] We just want to put our tents back up'. Her feeling was that 'hopes and aspirations [were] symbolised by the ragged embassy tent'. ${ }^{\text {. }}$.

The homelessness being symbolised in the Tent Embassy spoke to the widespread cultural and physical displacement of Aboriginal people across the continent. Aboriginal people were displaced by colonisation, and the stance of the McMahon Government offered little hope for improvement. Perhaps these two levels of symbolism are best captured by Gary Foley who remarked in 1972 that:

[t]he government [...] declared us aliens in our own land [...] [W]e need an Embassy just like all the other aliens. But our Embassy won't be a flash one $[\ldots]$ ours will be a tent, to symbolize the material conditions in which Aboriginal people are living. ${ }^{56}$ 
The Tent Embassy was (and is) much more than a tent purporting to be an Embassy. It embodied the struggles overshadowing Aboriginal life and offered a jarring insight into many Aboriginal people’s circumstances.

As both a symbol and an event, the Embassy embraced its ironic position for satirical effect. In Foley's words, this 'gentle irony [...] enabled the activists to make pompous government officials look like fools'. Humour, an excellent medium for fostering understanding in Australia, helped contribute to the Embassy's relatability for many Aboriginal people, but also 'appealed to the Australian larrikin sense of humour' ${ }^{57}$ It was powerful in three distinct but related ways: as a form of amusement, 'making fools out of government ${ }^{58}$ and communicating with the public. Activists were aware that their agitation was something of 'a wag's act'. ${ }^{59}$ The use of a beach umbrella on 26 January 1972 because a tent had yet to be located was symptomatic of the haphazard but highly amusing style now widely understood to be synonymous with the Embassy.

The Embassy's satire could be conveyed through both juxtaposition and good fortune. Foley, quoted by Muldoon and Schaap, has explained that 'satire and ridicule' were obvious choices to the Embassy's Aboriginal activists because 'Australian society, its political institutions and mythology were laughable [to Aboriginal people]'. ${ }^{60}$ The image on the opening pages of this article illustrates the rawest form of this juxtaposition, with Parliament House in all its grandeur and formality contrasted against a dilapidated-looking tent. Importantly, the aim was not to make light of the way Aboriginal people suffered from their position within Australia. The Embassy sought to undermine the Commonwealth to assert that Aboriginal people exist without it. This argument borrows from Muldoon and Schaap who observe the Embassy's ongoing 'indifference to the reconciliation process' and 'refusal to recognize the legitimacy of the Australian state which has incorporated [Aboriginal people] as citizens' ${ }^{61}$ Fortune favoured the brave in 1972; special Aboriginal exemption from laws against trespass established in lieu of dispossession and chronic homelessness enabled the protest to survive, endure and grow. ${ }^{62}$ As an event, the establishment of the Embassy became a stunt that 'humiliated'

57 Foley, 'A Reflection on the First Thirty Days of the Embassy', 23.

58 Howell, 'Black Power-By Any Means Necessary', 75.

59 Robinson, 'The Aboriginal Embassy', 7.

60 Muldoon and Schaap, 'The Constitutional Politics of the Aboriginal Embassy', 224.

61 Muldoon and Schaap, 'Aboriginal Sovereignty and the Politics of Reconciliation', 535.

62 Muldoon and Schaap, 'The Constitutional Politics of the Aboriginal Embassy', 231. 
government officials such as Minister Ralph Hunt, who Paul Coe alleges confessed his 'embarrassment' at the government's inability to manage the fiasco that the Embassy provoked. ${ }^{63}$

This article has sought to demonstrate that the Aboriginal Tent Embassy was, and still is, an important symbol that Aboriginal activists created and have continued to sustain since the 1970s—consciously and conscientiously. The Embassy consolidated the belief in the sovereignty of Aboriginal people as rightful custodians of the land, and more contemporaneous influences-including the Black Power movement and the effect of migration to urban areas in the 1950s and 1960s-helped foster an emerging pan-Aboriginal identity that more easily transcended 'national' boundaries. In this way it reflected the activists who created and nurtured it.

The tent as a symbol meant different things to the government of the day, and also to the Opposition, particularly its leader Gough Whitlam. Most importantly, however, the Embassy was a space designed to appeal to the shared experiences of Aboriginal people. By symbolising the resilience and displacement of Aboriginal people, the Embassy shed light on everyday hardship. The site itself was significant, projecting important Aboriginal issues into Canberra, in front of another great symbol, Parliament House. Moreover, the Embassy drew on Australian humour to further its cause. It satirised the Commonwealth and the relationship it had with Aboriginal people. Indeed, it continues to do so today, distinguishing itself from formal (state-sanctioned) symbols such as Reconciliation Place. ${ }^{64}$ The Embassy remains lively today, now juxtaposed against 'Old' Parliament House, fighting for the rights and interests of Aboriginal Australia.

63 Paul Coe speech, 30 July 1972, recorded by Derek Freeman, transcribed in 'Confrontation at the Embassy', in The Aboriginal Tent Embassy, 182.

64 Muldoon and Schaap, 'Aboriginal Sovereignty and the Politics of Reconciliation', 539-40. 
This text is taken from ANU Historical Journal II: Number 1, published 2019 by ANU Press, The Australian National University, Canberra, Australia.

doi.org/10.22459/ANUHJII.2019.08 